\title{
Ke Arah Guru Pendidikan Islam sebagai Pemikir Kritis
}

\author{
Nursafra Mohd Zhaffara*, Mohd Isa Hamzahª, Khadijah Abd Razaka, Wan Ali Akbar Wan Abdullah ${ }^{b}$
}

${ }^{a}$ Fakulti Pendidikan, Universiti Kebangsaan Malaysia, 43600 Bangi, Selangor

${ }^{b} S M K$ Undang Jelebu, 71600 Kuala Klawang, Negeri Sembilan

*Corresponding author: nursafra@kkjel.edu.my

\begin{abstract}
It is important in the teaching of Islamic Education to be infused with thinking skills so that students can inteprate Islamic teaching into their life context. Nevertheless, the implementation of it in the teaching of Islamic Education is seen as lacking in stimulating the students' thinking ability. It is crucial to ensure the Islamic Education teachers (IET) to develop their critical thinking attributes first before they implement it on their students. To develop this attribute among the teachers, it will not be easy since they have to allocate more time, more energy and a lot of systematic and continuous collaborations with other parties. Therefore, it is very important to highlight this issue. This study used content analysis methodology of previous research related to the development factors of IET as a critical thinker. This study found that there are two main factors including internal and external factors. These two factors are discussed based on the Ibn Khaldun Educational Theory and Dunkin \& Biddle Teaching and Learning Model. Hopefully this article contributes to the development of critical thinking quality among the Islamic Education teachers on their own individual effort or in the higher level towards the effective teaching of Islamic Education.
\end{abstract}

Keywords: Islamic education teachers; critical thinker; critical thinking skill, personal factor, external factor.

\begin{abstract}
Abstrak
Pengajaran Pendidikan Islam (PI) penting untuk diterapkan bersama kemahiran berfikir supaya murid berupaya mentafsir prinsip ajaran Islam ke dalam konteks kehidupan harian. Namun, pelaksanaan pengajaran PI sekolah menengah didapati kurang merangsang daya fikir murid. Keupayaan Guru Pendidikan Islam (GPI) sebagai pemikir kritis perlu dibangunkan terlebih dahulu kerana GPI yang berfikiran kritis lebih mudah menggilap kemahiran berfikir muridnya. Usaha membangunkan GPI kritis ini menuntut masa, tenaga dan kerjasama yang sistematik dan berterusan. Oleh itu, terdapat keperluan untuk hasil artikel ini diketengahkan. Melalui metodologi analisis kandungan daripada kajian-kajian lepas berkaitan faktor pembangunan GPI kritis, kajian mendapati terdapat dua faktor utama iaitu melibatkan faktor personal dan faktor luaran. Faktor-faktor ini dikupas berdasarkan Teori Pendidikan Ibn Khaldun dan Model Pengajaran dan Pembelajaran Dunkin dan Biddle. Artikel ini diharap menyumbang kepada pembangunan kualiti pemikiran kritis GPI sama ada inisiatif secara individu mahupun di peringkat lebih tinggi supaya perancangan boleh dirangka bagi menjayakan pengajaran PI yang berkesan.
\end{abstract}

Kata kunci: Guru Pendidikan Islam, Pemikir kritis, kemahiran berfikir kritis, faktor personal, faktor persekitaran.

(C) 2016 Penerbit UTM Press. All rights reserved

\subsection{PENGENALAN}

Kemahiran berfikir dan Pendidikan Islam (PI) tidak dilihat berjalan seiring berbanding subjek berbentuk saintifik dan teknologi (Mohd Zaidi, 2014). Hal ini disokong oleh pelaksanaan PI yang bersifat doktrin, rigid dan ketinggalan dari sudut menyediakan keperluan mendepani cabaran semasa (Ali Riaz, 2014; Rahimah et al., 2013; Rosnani Hashim et al., 2014; Tan \& Ding 2014). Walau bagaimanapun dalam PI, penguasaan kemahiran berfikir secara kritis penting untuk menjadikan murid mampu mentafsir prinsip dan ajaran Islam yang dipelajari ke dalam konteks kehidupan harian, meneliti dan membuat pertimbangan yang sesuai ketika menghadapi babak-babak kritikal dalam kehidupannya serta mengukuhkan pegangan sebagai seorang Muslim (Rosnani Hashim et al., 2014; Sidek Baba, 2009; Suhailah Hussien, 2007; Zakir Badwi, 1989). Kebiasaan memilih tindakan yang rasional berdasarkan ilmu dan nilai sebagai Muslim, bakal membentuk akhlak terpuji (Christina et al., 2014; Mohd Zaidi, 2013). Justeru, terdapat kepentingan pendekatan PI diolah agar pedomanpedoman bersumberkan wahyu dapat diterjemah dalam bentuk aplikasi seiring dengan peranan Islam sebagai cara hidup. Sebaliknya, kelemahan dalam pendekatan ini hanya akan menyebabkan ajaran-ajaran Islam kekal sebagai ritual harian yang kurang berimpak meluas (Wan Mohd Zahid, 1993).

Kajian-kajian lepas menunjukkan bahawa pemikiran kritis murid sekolah menengah dipengaruhi oleh kualiti dan corak pengajaran guru (Marin \& Halpern, 2011; Phillips, 2013; Points, 2003; Rahmat, 2005; Raths et al., 1986; Rosnani et al., 2014; Sabri, 2008). Pelaksanaan pengajaran yang merangsang pemikiran kritis memerlukan integrasi kemahiran berfikir ke dalam kandungan pelajaran, penyoalan aras tinggi, cara merespon dan permodelan oleh guru yang mencambah potensi pemikiran murid (Costa, 1991c; Halpern, 1998; Swartz, 1991). Namun, kelemahan tersebut dikesan dalam kalangan GPI sekolah menengah di Malaysia. Pengajaran yang dikendalikan bersifat dogmatik; bertumpu kepada teks wahyu dan amalan ritual serta penggunaan kaedah pengajaran yang kurang meningkatkan daya intelek murid (Ab. Halim \& Zarin Ismail, 2006; Kamarulzaman \& Mohd Aderi, 2006; Misnan, 2008; Mohd Aderi \& Ahmad Yunus, 2012; Nurul Asiah Fasehah, 2015; Rosnani Hashim, 1996; Rosnani Hashim et al., 2014; Syed Najmuddin, 2009; Zakaria, 2012). Manakala, kajian Suhailah (2009) menunjukkan guru lebih berkesan mengendalikan pengajaran berfikir sekiranya guru tersebut seorang yang kritis. 
Oleh yang demikian, bagi memangkin pengajaran PI bercorakkan pemikiran kritis, GPI perlu diasuh sebagai pemikir kritis untuk melahirkan murid yang kritis (Rosnani Hashim, 2012).

\subsection{KERANGKA KONSEP: PEMBANGUNAN GURU PENDIDIKAN ISLAM KRITIS}

Pemikiran kritis didefinisikan sebagai membuat pertimbangan dan penilaian kualiti sesuatu maklumat bertujuan untuk memutuskan tindakan dan kepercayaan (Beyer, 1995; Ennis 1985). Siapakah yang dikatakan guru yang kritis? Ibn Khaldun tidak menyatakan secara langsung perkataan kritis dalam teori pendidikannya. Secara umumya, Ibn Khaldun mengaitkan kebiasaan, kecenderungan atau habit (malakah) seseorang dengan persekitarannya. Ibn Khaldun menjelaskan kebiasaan seorang guru berfikir dengan meneliti peristiwa yang dihadapinya dan menyaring konsep yang difikirkan berguna ke arah mencapai kebenaran; akan membuatkannya mudah memahami perkara-perkara dasar, dapat mengembangkan perkara asas dan mampu menyelesaikan persoalan-persoalan yang timbul daripada sesuatu prinsip ilmu. Proses yang dijelaskan oleh Ibn Khaldun ini melibatkan penelitian dan penilaian maklumat yang merupakan kunci utama kepada pemikiran kritis (Beyer, 1995). Kecenderungan guru membuat refleksi kritis ke atas maklumat yang diperoleh menjadikannya seorang yang menguasai secara mendalam konsep sesuatu ilmu itu.

Seterusnya, faktor persekitaran sosial dianggap penting sebagai pemangkin kepada daya berfikir individu. Nilai yang terbentuk dalam persekitaran sosial mempengaruhi kebolehan individu berfikir (Ibn Khaldun, 1967). Dalam hal ini, ahli falsafah dalam pemikiran kritis menjelaskan pemikiran kritis sesuai dibangunkan dalam konteks pembelajaran sosial dengan mewujudkan komuniti berfikir (Brookfield, 2003; Rosnani Hashim, 2009). Justeru, model Dunkin dan Biddle (1974) didapati selari dengan Teori Ibn Khaldun di mana pembangunan kualiti pemikiran guru itu dipengaruhi oleh faktor personal dan faktor persekitaran. Gabungan kedua-dua teori dan model ini diringkaskan dalam rajah 1:

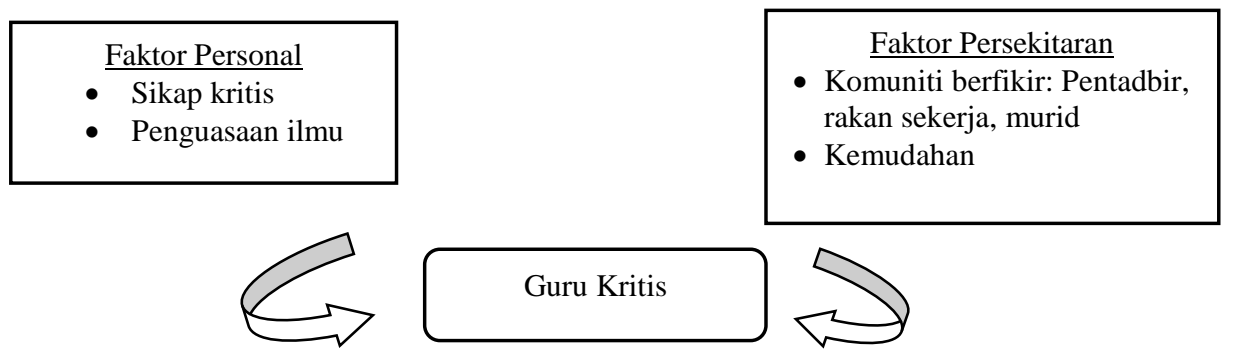

Rajah 1 Kerangka konsep pembangunan GPI kritis

Tugas melahirkan pemikir yang kritis bukan usaha yang mudah, malah memerlukan masa, tenaga dan iltizam (Paul, 1990) serta dokongan daripada persekitaran (Costa, 1991a; Ibn Khaldun, 1967). Seterusnya dibincangkan faktor personal dan persekitaran yang mendorong kepada pembentukan GPI kritis berdasarkan kombinasi Teori Ibn Khaldun dan model Dunkin dan Biddle.

\subsection{FAKTOR PERSONAL KEPADA PEMBANGUNAN GPI KRITIS}

\subsection{Sikap kritis}

Sikap kritis ialah kecenderungan atau motivasi dalaman (disposition) untuk meneliti sesuatu maklumat dan membuat keputusan menggunakan pemikiran kritis (Facione, 1990). Dalam menempuh sesuatu situasi atau masalah, individu boleh memilih sama ada untuk menyelesaikannya secara kritikal ataupun tidak. Disebabkan berfikir kritis memerlukan usaha gigih, maka kewujudan faktor sikap inilah yang mempengaruhi keberkesanan berfikir sama ada mengaplikasi kemahiran tersebut atau memendamkannya (Halpern, 1998; Norris, 1985; Ruggiero, 2012; Siegel, 2010; Tishman et al., 1993). Walaupun sarjana menggelarkan kecenderungan ini dengan panggilan berbeza, seperti; semangat kritis seorang pemikir (Ennis, 1987) atau tabiat minda (Case, 2005; Costa \& Kallick, 2009), namun ia dicirikan sebagai komitmen kepada prinsip pemikiran yang baik seperti mempunyai minda terbuka, adil, fleksibel terhadap isu yang kabur, berusaha meneroka justifikasi, mengumpul maklumat secara optimum, mempunyai inkuiri yang tinggi dan memantau proses pemikiran sendiri (Boss, 2015; Case, 2005; Costa \& Kallick, 2009; Ennis, 1985, 1993; Facione, 2000; Halpern, 1998; Norris, 1985; Tishman et al., 1993; Paul, 1985).

Dalam konteks ini, GPI dilihat sebagai golongan yang telah terdedah kepada proses berfikir secara kritis sekurang-kurangnya semasa pengajian di peringkat siswazah. Sebagai ahli profesion akademik, memiliki ijazah berlatarbelakangkan Pengajian Islam atau pun Pendidikan Islam, GPI telah terdedah kepada bentuk-bentuk perbahasan ulama' atau pun penelitian ilmiah ahli akademik ke arah mencapai satu keputusan melalui kurikulum di institusi pengajian tinggi. Contohnya, GPI yang mengambil pengkhususan Fiqh dan Usul Fiqh, mereka telah terbiasa mengumpul pelbagai pandangan ulama' serta meneliti kekuatan setiap pandangan sebelum membuat kesimpulan dalam sesuatu isu perbahasan. Contoh lain, GPI graduan pengkhususan Al-Quran dan Sunnah, mereka mempelajari kaedah menilai sesuatu periwayatan hadis sama ada melalui sanad mahupun matan. Turut ditekankan bagaimana cara pandang kepada ayat-ayat al-Quran dan hadis-hadis yang kelihatan zahirnya bertentangan antara satu sama lain. Begitu juga dengan GPI pengkhususan Pendidikan Islam yang telah terdedah kepada proses mencari titik temu antara kandungan pelajaran dan kesesuaiannya dengan pedagogi untuk mencapai objektif pengajaran. Maka, subjek yang ditawarkan seperti Takhrij al-Hadis, Al-Qawa'id al-Usuliyyah wa Ikhtilaf al-Fuqaha', Contemporary Issues in Usul al-Din, Al-Fiqh al-Muqaran (Portal MyIIUM, 2015) dan lain-lain telah mewarnai latar belakang pengalaman GPI untuk menjadi seorang pemikir kritis. 
Seterusnya, pengalaman inilah yang harus disuburkan sehingga mendasari sikap GPI dalam merespon kepada situasi kehidupannya di sekolah mahu pun di luar sekolah. GPI boleh bermula dengan memberi masa kepada minda untuk merenung isu-isu penting seperti pemilihan bahan pengajaran yang mampu merangsang perkembangan intelek dan sesuai dengan murid (Norris, 1985; Winn, 2004). Kebiasaan yang dibudayakan ini mampu membawa kepada faktor seterusnya iaitu penguasaan ilmu (Ibn Khaldun, 1967; al-Qardawi, 2004; al-Zarnuji, 2004).

\subsection{Penguasaan Ilmu}

Aktiviti berfikir kritis memerlukan objek dan konteks untuk difikirkan. Dalam hal ini, ilmu diperlukan kerana individu perlu menggunakan pengetahuan sedia ada, pengalaman dan common sense ke dalam skop pemikiran (Malik Badri, 2000; Norris, 1985). Ilmu yang mendalam dan meluas berkaitan topik difikirkan menjadikan seseorang mempunyai maklumat relevan yang diperlukan untuk berfikir kritis (Bailin et al., 1999; Case, 2005). Misalnya dalam pengajaran ibadah, GPI yang mempunyai pengetahuan yang luas mengenai jual beli insurans mampu memandu murid merumus prinsip-prinsip jual beli dan isu-isu berkaitan insurans. Pendedahan kepada murid boleh diberi tentang perkembangan terkini produk insurans di pasaran. Namun, sekiranya pengetahuan tentang topik tersebut kurang, maka GPI tidak dapat memberikan gambaran bagaimana idea-idea dapat dikaitkan antara satu sama lain, merentasi bidang berbeza mahupun pertaliannya dengan kehidupan harian murid di mana aplikasi pemikiran kritis boleh berlangsung (Darling-Hammond, 2008).

Al-Ghazali (1988) menekankan kepentingan penguasaan ilmu oleh para guru, bukan sekadar memaparkan pandangan-pandangan ilmuwan lain berkaitan sesuatu topik, bahkan berkemampuan merumuskan dan menyatakan pendiriannya dalam isu yang diperbahaskan. Hal ini kerana menurut al-Ghazali, orang buta (hanya bertaklid kepada pandangan orang) tidak dapat memimpin orang buta yang lain. Tiga komponen asas dikenal pasti sebagai ilmu yang perlu dikuasai oleh GPI yang merupakan intisari ajaran Islam (al-Ghazali, 1988; Hasan Langgulung, 1986; Noornajihan Jaafar, 2014) ialah ilmu akidah, ibadah dan akhlak. Hal ini berdasarkan kepada hadis pertanyaan Jibril

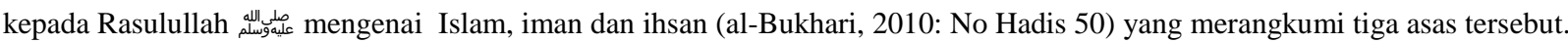

Walau bagaimanapun, lantaran sifat ilmu yang teramat luas, al-Zarnuji (2004) dan al-Ghazali (1988) membataskan kewajipan menguasai ilmu kepada yang bersangkut-paut dengan keadaan dan urusan kehidupan harian kita. Dalam konteks ini, selain ilmu pengetahuan agama, GPI juga perlu menguasai asas pengetahuan lain seperti Sejarah, Georgrafi, Sains dan sebagainya (Ab. Halim \& Mohamad Khairul Azman, 2010). Namun, GPI tidak perlu mengetahui dengan terperinci istilah saintifik seperti proses perubahan dalam molekul-molekul air, namun cukup dengan mengetahui sifat asas air yang boleh berubah mengikut keadaan. Tujuannya agar GPI mampu memperkayakan sesuatu konsep yang diajar melalui perkaitannya merentasi pelbagai disiplin ilmu. Maka dengan ini murid dapat melihat satu konsep secara kritis daripada pelbagai dimensi (Halpern, 1998).

Isunya di sini ialah sejauh mana kedalaman ilmu yang GPI perlukan supaya berkeyakinan mengajar pemikiran kritis dalam kandungan PI? Al-Zarnuji (2004) menjelaskan bahawa sesuatu ilmu dapat dikuasai melalui kesungguhannya meneliti daripada sudut-sudut yang dipelajari beserta hikmahnya. Pandangan beliau ini berdasarkan firman Allah dalam Surah Al-Ankabūt (29: 69):

Maksudnya: " Dan orang-orang yang berusaha dengan bersungguh-sungguh kerana memenuhi kehendak agama kami, sesungguhnya kami akan memimpin mereka ke jalan-jalan kami (yang menjadikan mereka bergembira serta beroleh keredhaan); dan sesungguhnya (pertolongan dan bantuan) Allah adalah beserta orang-orang yang berusaha membaiki amalannya."

(Abdullah Muhamad Basmeih, 2011: 865)

Maka, dapat difahami bahawa GPI perlu menghadam satu-satu konsep dalam topik pengajarannya daripada sudut yang berbeza (Ahmad Tafsir, 2002). Contohnya dalam pengajaran konsep sifat Allah ar-Rahmān. Sifat pemurah (ar-Rahmān) ini boleh dilihat dalam konteks pemurahnya manusia kepada sesama manusia lain, haiwan dan tumbuhan, serta boleh juga dilihat dalam konteks pemurahnya Allah kepada makhluk-Nya. Perbandingan dapat dilakukan untuk menghasilkan satu konklusi konkrit berkaitan konsep ar-Rahmān yang dipegang sebagai persediaan untuk menjalankan pengajaran berkesan.

Dalam keghairahan menguasai ilmu, GPI juga perlu mengetahui sempadan peranan akal dalam konteks pengajaran kemahiran berfikir kritis. Sebagaimana Qutb (2001) menjelaskan pendidikan akal dalam Islam bermula dengan meletakkan had pandangan akal sebelum potensi tersebut dipupuk untuk mencapai keyakinan. Batasan tersebut bertujuan meraikan fungsi akal yang hanya berkemampuan mencapai daerah yang bersifat zahir sahaja. Dalam hal ini, Islam sebagai agama fitrah meletakkan batasan penggunaan akal bagi tujuan pemikiran kritis khususnya bersangkutan dengan perkara akidah iaitu terdiri daripada empat perkara; a) berfikir tentang hakikat zat Allah, b) berfikir mengenai perkara sam'iyyat merangkumi persoalan syurga, neraka, al-mizān, dosa, pahala, roh, kenabian dan lain-lain, c) hukum-hukum fekah iaitu halal, haram, wajib, sunat dan lain-lainnya, d) perilaku akhlak manusia merangkumi sifat mahmudah dan mazmumah (Abdul Halim Mahmud, 1995; Hasan Langgulung, 1986; Muhammad Rashidi \& Mohd Faizul, 2013; Noor Hisham, 2014; Shihab, 2005). Ringkasnya, GPI perlu membezakan kandungan pelajaran PI sama ada bersangkutan dalam perkara yang boleh diperbahaskan atau pun perkara yang perlu diimani semata (Ahmad Tafsir, 2002).

Ibn Khaldun (1967) pula menyarankan kaedah menguasai ilmu ialah melalui latihan bertutur dan menulis. Kedua jenis aktiviti ini dipanggil sebagai alat berfikir (Ainon \& Abdullah, 1994) kerana berperanan membantu keupayaan mengemukakan pendapat dan kemahiran menyusun idea secara logik ke arah satu rumusan. Ini disokong oleh al-Zarnuji di mana beliau lebih menggalakkan perbincangan, pertukaran idea berbanding pengulangan ilmu secara hafalan semata. Ini kerana aktiviti perbincangan mengandungi elemen pengulangan dan penambahan ilmu melalui pengamatan serta memperhalusi pernyataan yang benar. Maka, GPI boleh membina penguasaan ilmu secara aktif melalui perbincangan dengan rakan sekerja, membentang di seminar bersama pakar bidang, memberi ceramah, menghasilkan penulisan berbentuk artikel, buku atau kertas kerja dan sebagainya.

Selain daripada ilmu kandungan, turut diberi perhatian ialah ilmu yang berfungsi membantu penyampaian kandungan iaitu bersangkutan dengan perihal pemikiran kritis. Ini merangkumi ilmu pengetahuan tentang strategi mengaplikasi pemikiran kritis, pengetahuan tentang kriteria penilaian dan pengetahuan tentang konsep utama pemikiran kritis (Bailin et al., 1999; Underbakke et al., 1993). Inilah yang dinamakan ilmu alat; ilmu yang digunakan untuk mempelajari ilmu lain yang lebih utama (Hasan Langgulung, 1986). Ilmu ini relevan kerana kajian-kajian menunjukkan pelaksaan pengajaran lebih berkesan apabila kemahiran berfikir kritis berlaku secara 
eksplisit; guru mengajak murid menggunakan aras kemahiran berfikir tertentu dan murid mengaplikasikannya secara sedar (Marin \& Halpern, 2011).

\subsection{FAKTOR PERSEKITARAN KEPADA PEMBANGUNAN GPI KRITIS}

\subsection{Komuniti Berfikir}

Komuniti berfikir merujuk kepada masyarakat sekeliling yang berada hampir dengan GPI iaitu pentadbir sekolah, rakan guru dan para murid. Dalam konteks sekolah sebagai sebuah masyarakat, budaya atau iklim yang terkandung di dalamnya mempengaruhi pemikiran dan tingkah laku warganya. Budaya ini membentuk satu corak atau kod etika warganya dalam kebanyakan keadaan termasuk dalam situasi penyelesaian masalah dan pembuatan keputusan (Ibn Khaldun, 1967).

Penguasaan ilmu menjadi lebih mudah sekiranya GPI itu sendiri membudayakan ilmu dalam dirinya. Adel al-Syaraf (2013) mengaitkan seorang pemikir kritis dengan ciri orang bertaqwa iaitu kesanggupan belajar sepanjang hayatnya. Individu berbudaya ilmu akan meletakkan matlamat memburu ilmu sebagai nilai tertinggi dalam hidupnya seperti yang digambarkan dalam kehidupan sarjanasarjana Islam pada zaman kegemilangan Islam di mana mereka sanggup berbelanja, mengembara, memperuntukkan masa untuk mendapat ilmu dan menyebarkannya. Namun, budaya ini perlu dipupuk dalam sebuah persekitaran di mana setiap ahlinya saling menyokong. Dalam konteks sekolah, budaya ilmu ini penting kerana peningkatan kejayaan murid dapat ditentukan daripada tahap peningkatan ilmu guru (Burnham \& O'Sullivan, 2010; Hill et al., 2005).

Costa (1991a) berpandangan bahawa guru-guru memerlukan rangsangan persekitaran dalam membangunkan pemikiran kritisnya dan seterusnya menjayakan pengajarannya. Kajian (Simon, 2010) mendapati bentuk iklim sosial sekolah yang menyumbang terhadap amalan pengajaran berfikir kritis ialah penyertaan dalam membuat keputusan. Ini selari dengan teori pemikiran kritis yang menyatakan peluang memainkan peranan membuat keputusan akan mempertingkatkan kemahiran-kemahiran berfikir kritis seperti meramal, menganalisis, mensintesis dan membuat rumusan. Guru-guru yang biasa didedahkan dengan amalan membuat keputusan secara kolektif dalam pengurusan, akan mempunyai rasa dipercayai dan bertanggungjawab terhadap keputusan itu (Costa, 1991a; Wan Mohd. Zahid, 1993).

Seterusnya, kajian Preus (2012) memaparkan sudut pandang berbeza di mana kewujudan budaya hormat-menghormati menjadi kunci kelancaran pelaksanaan pengajaran aras tinggi. Sikap hormat pengetua kepada para guru dan meyakini kebolehan guru mencungkil potensi berfikir murid mencorakkan budaya yang sama ke dalam kelas. Dua kajian ini menggambarkan bahawa pentadbir sekolah mempunyai peranan dalam menyusun sistem pentadbirannya supaya dapat mengambilkira pandangan dan kepakaran guru-guru dalam isu-isu pengurusan sekolah seperti pengajaran dan disiplin murid (Tang \& Thanaletchumy, 2015).

Selain itu, pengaruh rakan sekerja juga mampu meningkatkan refleksi (Malik Badri, 2000). Kebolehan membuat refleksi ini merupakan ciri penting seorang pemikir kritis (Ennis, 1987; Meyers, 1986). Darling Hammond (2008: 93) menyatakan: "Guru belajar seperti mana murid mereka belajar; melakukan dan membuat refleksi, melalui kolaborasi dengan guru-guru lain, dengan melihat secara dekat murid dan kerjayanya, dan berkongsi apa yang mereka lihat."

Persahabatan dengan rakan sekerja mampu menjadi medan perkongsian pengajaran (Parwazalam et al., 2014). Guru secara berterusan membincangkan amalan pengajaran secara mendalam dalam bahasa yang sama untuk menggambarkan kompleksiti pengajaran (Burnham \& O'Sullivan, 2010). Daripada sini, bimbingan berbentuk dua hala dapat saling dimanfaatkan oleh sesama guru. GPI dapat memanfaatkan rakan sekerja dengan belajar daripada pengalaman hariannya, saling bertukar pandangan dan kepakaran dalam menyelesaikan isu pengajaran dan sebagainya. Sebagaimana anjuran Allah (Ali Imran, 3:159) di mana Rasulullah فلئل sendiri selaku guru pertama kita turut bermusyawarah dan menjelaskan bahawa bermusyawarah menjadi asbab mendapat kebenaran (asy-Syalhub, 2014);

Maksudnya:" ...dan bermesyuaratlah dengan mereka dalam urusan (peperangan dan soal-soal keduniaan) itu.”

(Abdullah Muhamad Basmeih 2011: 132)

Di samping itu, pengalaman yang guru alami dalam kerjasama kumpulan melaksanakan aktiviti-aktiviti anjuran sekolah secara tidak langsung merangsang pemikiran kritis guru dan meningkatkan prestasi pengajaran. Namun, ini berkesan sekiranya amalan refleksi dilakukan melibatkan (Natale \& Ricci, 2006):

- Kesedaran: Apa sahaja peristiwa yang merangsang penilaian kritis seperti rasa tidak puas hati atau situasi yang boleh diambil pelajaran.

- Analisis kritikal: Menggunakan pengetahuan yang relevan dan ilmu yang baru hasil daripada proses analisis.

- Pembelajaran: Pembinaan ilmu dari perspektif baru hasil daripada proses analisis dan aplikasikannya kepada situasi yang sedang direflek.

Kajian (Parwazalam et al., 2014) mengenai budaya sekolah di sekolah menengah Malaysia mendapati bahawa ia berkolerasi dengan pembelajaran guru. Dua konstruk budaya sekolah iaitu komunikasi dan efikasi kolektif menyumbang kepada tahap pembelajaran guru. Dapatan ini menunjukkan bahawa guru perlu digalakkan bekerja secara berkolaboratif bersama rakan-rakan guru. Melalui komunikasi, guru dijangkakan lebih bersikap reflektif dan dapat mengembangkan budaya kolaboratif yang bukan sahaja bermanfaat kepada pembelajaran guru, malahan kepada pencapaian murid. Di sini datangnya peranan PLC (Professional Learning Community) yang diperkenalkan dan dipromosikan oleh KPM untuk dibudayakan oleh para guru. Melalui elemen-elemen PLC seperti lesson study, peercoaching, teacher sharing session, kritikan video dan learning walk; para guru dapat melihat dan menilai kaedah pengajaran rakan guru, mengkritik, mencari kelemahan dan memberikan cadangan penambahbaikan secara kolektif (Kementerian Pendidikan Malaysia, 2014b). 
Cadangan penambahbaikan kaedah pengajaran itu akan dicuba oleh rakan guru yang lain di kelas yang lain dan dinilai kembali oleh ahli PLC tersebut untuk berterusan mengkaji dan mencari kaedah terbaik yang boleh digunakan. Ia secara langsung menjadi proses pembelajaran sesama guru dan mampu memberikan impak dan kesan kepada pencapaian murid.

Murid turut memain peranan ke arah menggilap kemahiran GPI dalam berfikir secara kritis. Hal ini kerana menurut teori Ibn Khaldun, masyarakat sekeliling mempunyai kaitan dengan daya fikir individu. Maka, murid juga tergolong sebagai salah satu daripada kelompok berhampiran guru di sekolah. Dalam konteks pemupukan sikap kritis, guru perlu bersikap terbuka (open-minded) (Ennis, 1985), terutama untuk menerima pandangan daripada murid yang mungkin berbeza atau bercanggah dengan pandangan guru. Sikap ini selari dengan sifat tawadhuk yang diperlukan oleh seorang guru (Abdul Salam, 2003; asy-Syalhub, 2014) iaitu apabila berhadapan dengan lontaran pendapat, persoalan dan idea daripada murid, guru perlu tunduk kepada kebenaran walaupun daripada pihak anak didiknya. Oleh itu, dapat difahami bahawa kelompok murid yang mempunyai semangat ingin tahu, gemarkan perbincangan dan suka melontarkan persoalan dapat mengarahkan gurunya juga menganalisis secara kritis. Ini kerana antara tanggungjawab GPI untuk menghilangkan keraguan anak didiknya sebelum setiap pelajaran berakhir (Ibn Khaldun, 1967).

\subsection{Kemudahan}

Berfikir secara kritis memerlukan usaha pengumpulan maklumat. Tanpa maklumat yang mencukupi, proses pertimbangan menjadi terhad atau mungkin tertangguh (Bailin et al., 1999). Bagi memupuk sikap kritis dalam diri guru mahupun murid memerlukan sokongan kemudahan sumber maklumat yang luas dan cukup (Costa, 1991b). Misalnya GPI yang dilontarkan persoalan oleh murid mengenai isu semasa, dengan mudah mampu merujuk kepada buku-buku, majalah, laman sesawang mahupun perisian komputer seperti Maktabah AlSyamilah untuk memahami konteks persoalan, mencari kedudukan hadis, memahami fatwa ulama' dahulu dan kini serta berbagai lagi kaedah dan cara yang mampu membantu GPI menganalisis. Di samping itu, kemudahan perpustakaan yang lengkap memudahkan GPI memilih bahan terbaik yang relevan dengan isi pelajaran untuk direflek bersama murid. Maka, kemudahan teknologi maklumat dan komunikasi yang kementerian sediakan seperti 1BestariNet yang berteknologi 4G, platform pembelajaran maya seperti VLE Frog, panduan dan contoh pengajaran terbaik daripada Portal e-Guru (Kementerian Pendidikan Malaysia, 2014a), seminar-seminar inovasi dan kajian tindakan serta program PLC (Kementerian Pendidikan Malaysia, 2014b) dikira membantu pembentukan GPI kritis sekiranya dimanfaatkan secara optimum.

Selain kemudahan berbentuk fizikal, kemudahan latihan dalam perkhidmatan yang terancang dan berterusan juga dapat membantu GPI mengasah kemahiran berfikir kritis. Program latihan ini boleh dianjurkan berperingkat dengan mengkhususkan aplikasi pedagogi ke dalam subjek Pendidikan Islam mahupun berbentuk bengkel umum berkaitan latihan pemikiran kritis. Manfaat daripada 7 hari kursus yang diwajibkan dalam setahun perlu dioptimumkan oleh para GPI. Jika kursus yang dihadiri tidak mencukupi tempoh setahun, maka pembelajaran masih boleh diperoleh melalui pembelajaran kendiri yang diiktiraf oleh Kementerian Pendidikan Malaysia (KPM). Aktivitiaktiviti pembelajaran kendiri tersebut adalah seperti; 1) pembacaan buku, 2) pembelajaran online, 3) penyelidikan dan kajian tindakan, 4) penulisan/penulisan pengkaryaan di luar bidang tugas, 5) program sandaran/sangkutan organisasi luar KPM, 6) sumbangan lain bukan professional/ aktiviti kesukarelaan, dan 7) peningkatan akademik (e-SPLG, 2015; Kementerian Pendidikan Malaysia, 2014b).

Di samping itu, GPI boleh dihantar menghadiri seminar dan bengkel yang membolehkan mereka bergaul dan berkongsi pengalaman bersama ahli akademik yang lain. Ruang untuk berkarya, refleksi ilmu dan pengalaman sama ada dalam bentuk penulisan mahu pun lisan juga perlu diadakan berterusan. Setakat ini, program-program anjuran Bahagian Pendidikan Islam (BPI), KPM seperti Pertandingan Sayembara-Info Grafik, penerbitan buku koleksi artikel dan tazkirah daripada GPI seluruh Malaysia dan sebagainya dilihat dapat dijadikan wadah untuk GPI menyusun, membuat refleksi kreatif, menilai dan memindahkan buah fikiran kepada ilmu baru untuk dimanfaatkan bersama.

\subsection{KESIMPULAN}

Sebagai kesimpulan, GPI secara individu telah sedia terdedah kepada pemikiran kritis di pusat pengajian tinggi. Begitu juga dengan ilmuilmu asas kandungan Pendidikan Islam berkaitan akidah, syariah dan akhlak. Inisiatif peribadi daripada pihak GPI untuk menggilap potensi ini diperlukan dengan membudayakan ilmu. Melalui pembudayaan ilmu ini, sikap kritis dan penguasaan ilmu dapat diraih. Bagi menjamin inisiatif ini berterusan, GPI memerlukan sokongan persekitaran iaitu daripada pentadbir, rakan sekerja, murid dan kemudahan yang lengkap. Sekiranya suasana berfikir telah membudaya dari dalam dan luar, maka GPI dijangka berupaya melaksanakan pengajaran PI bercorakkan pemikiran kritis dengan berkesan.

\section{Rujukan}

Ab. Halim Tamuri \& Mohamad Khairul Azman Ajuhary. (2010). Amalan Pengajaran Guru Pendidikan Islam Berkesan Berteraskan Konsep Mu'allim. Journal of Islamic and Arabic Education, 2(1), 43-56.

Ab. Halim Tamuri \& Zarin Ismail. (2006). Model guru pendidikan Islam: Konsep 5 mim. Kertas kerja Seminar Amalan Pengajaran Guru Pendidikan Islam, 1 April. Abdul Halim Mahmud. (1995). Islam \& Akal. Terj. Mohd Fakhrudin Abd Mukti. Kuala Lumpur: Dewan Bahasa \& Pustaka \& Kementerian Pendidikan Malaysia. Abdul Salam Yussof. (2003). Imam Al-Ghazali: Pendidikan Berkesan. Kuala Lumpur: Utusan Publications \& Distributors Sdn. Bhd. Abdullah Muhammad Basmeih. (2011). Tafsir Pimpinan Ar-Rahman kepada Pengertian Al-Quran. Selangor: Darul Fikir.

Adel Al-Sharaf. (2013). Developing Scientific Thinking Methods And Applications In Islamic Education. Education, 133(3), 272-282.

Ahmad Tafsir. (2002). Metodologi Pengajaran Agama Islam. Bandung: Penerbit PT Remaja Rosdakarya.

Ainon Mohd \& Abdullah Hassan. (1994). Teknik Berfikir: Konsep dan Proses. Kuala Lumpur: Utusan Publications \& Distributors Sdn. Bhd.

al-Bukhari, Muhammad bin Ismail. (2010). Shahih al-Bukhari Jilid 1. Jakarta: Pustaka As-Sunnah.

al-Ghazali. (1988). Ihya Ulumiddin Jiwa Agama. Terj. Ismail Yakub, TK.H. Edisi Malaysia. Kuala Lumpur: Victory Ajensi.

Ali Riaz. (2014). Madrassah Education in Bangladesh: Contestations and accommodations. Dlm. Sa'eda Buang \& Phyllis Ghim-Lian Chew. Muslim Education in the $21^{\text {st }}$ Century. New York: Routledge: 12-35. 
al-Qardawi, Yusuf. (2004). Taysir al-Fiqh Li al-Muslim Al-Mua 'sir fi Dhou'i al-Quran wa As-Sunnah. Qaherah: Maktabah Wahbah. al-Zarnuji, Burhan al-Islam. (2004). Ta'lim al-Muta'alim Thariq al-ta'llum. Sudan: Al-Dar Al Soudania for Books.

Asy-Syalhub, Fuad Abdul Aziz. (2014). Begini Seharusnya Menjadi Guru (Al-Mu'allim al-Awwal). Jakarta: Darul Haq

Bailin, S., Case, R., Coombs, J. R. \& Daniels, L. B. (1999). Conceptualizing critical thinking. Journal Curriculum Studies, 31(3), 285-302.

Beyer, B. K. (1995). Critical Thinking. Indiana: Phi Delta Kappa Educational Foundation.

Boss, J. A. (2015). ThiNK: Critical Thinking and Logic Skills for Everyday Life. New York: McGraw-Hill Education.

Brookfield, S. (2013). Teaching for Critical Thinking. International Journal of Adult Vocational Education and Technology, 4(1), 1-15.

Burnham, J. W. \& O'Sullivan, F. (2010). Mengembangkan Profesionalisme di Sekolah. Terjemahan Hamidah Baba. Kuala Lumpur: Institut Terjemahan Negara Malaysia Berhad \& Institut Aminuddin Baki.

Case, R. (2005). Moving Critical Thinking To The Main Stage. Education Canada, 45(2), 45-49.

Christina Andin, Hafizah Harun, Sarimah Ismail, Rohana Hamzah, Abdul Said Ambotang. (2014). Islamic Perspective On Teaching Thinking Skills. Prosiding World Conference on Islamic Thought and Civilization.

Costa, A. L \& Kallick, B. (2009). Habits of Mind: Across the Curriculum Practical and Creative Strategies for Teachers. Alexandria: Association for Supervisoin and Curriculum Department.

Costa, A.L. (1991a). The Principle's Role In Enhancing Thinking Skills. Dlm. Costa, A.L. Developing Minds: a resourse book for teaching thinking. Revised Edition Volume 1. USA: Association for Supervision and Curriculum Development: 35-38.

Costa, A.L. (1991b). The school as the home for the mind. Dlm. Costa, A.L. Developing Minds: a resourse book for teaching thinking. Revised Edition Volume 1 . USA: Association for Supervision and Curriculum Development: 47-54

Costa, A.L. (1991c). Teacher Behaviours That Enable Student Thinking. Dlm. Costa, A.L. Developing Minds: a resourse book for teaching thinking. Revised Edition Volume 1. USA: Association for Supervision and Curriculum Development: 194-206.

Darling-Hammond, L. (2008). Teacher Learning that Supports Student Learning. Presseisen, B. Z. Teaching for Intelligence Second Edition. USA: Corwin Press.

Dunkin, M.J. \& Biddle, B. J. (1974). The Study of Teaching. USA: Holt, Rinehart and Winston, Inc.

Ennis, R. H. (1985). A logical basis for measuring critical thinking skills. Educational Leadership, 45-48.

Ennis, R. H. (1987). A Taxanomy of Critical Thinking Dispositions and Abilities. Dlm. Baron, J. B \& Sternberg, R. J. Teaching Thinking Skills: Theory and Practice. New York: W.H. Freeman and Company: 9-26.

Ennis, R. H. (1993). Critical Thinking Assessment. Theory Into Practice, 32(3), 179-186.

e-SPLG. 2015. Sistem Pengurusan Latihan Kementerian Pendidikan Malaysia. Diakses daripada https://splkpm.moe.gov.my/i_splg/utama.cfm?nokp=840730115531\&IDP=840730115531\&pd=1 [20 Oktober 2015].

Facione, P.A. (1990). Critical Thinking: A Statement Of Expert Consensus For Purposes of Educational Assessment and Instruction. American Philosphical Association.

Facione, P.A. (2000). The Disposition toward Critical Thinking: Its Character, Measurement, and Relationship to Critical Thinking Skill. Informal Logic, 20(1), 61-84.

Halpern, D. F. (1998). Teaching Critical Thinking for Transfer Across Domains: Dispositions, Skills, Structure Training, and Metacognitive Monitoring. American Psychologist, 53(4), 449-455.

Hasan Langgulung. (1986). Pengenalan Tamadun Islam dalam Pendidikan. Kuala Lumpur: Dewan Bahasa dan Pustaka.

Hill, H. C., Rowan, B. \& Ball, D. L. (2005). Effects Of Teachers' Mathematical Knowledge For Teaching On Student Achievement. American Educational Research Journal, 42(2), 371-406

Ibn Khaldūn, Abd Ar-Rahman Muhammed. (1967). The Muqaddimah. Terj. Franz Rosenthal. Princeton, N. J: Princeton University Press.

Kamarulzaman Abdul Ghani \& Mohd Aderi Che Noh. (2006). Amalan Pengajaran Guru Pendidikan Islam Mengikut Persepsi Pelajar. Kertas kerja Seminar Amalan Pengajaran Guru Pendidikan Islam. Anjuran Universiti Kebangsaan Malaysia di Bilik Senat, Bangunan Canselori, 1 April.

Kementerian Pendidikan Malaysia. (2014a). Laporan Tahunan 2013 Pelan Pembangunan Pendidikan Malaysia, Jun.

Kementerian Pendidikan Malaysia. (2014b). Pelan Pembangunan Profesionalisme Berterusan (Guru dan Pemimpin Sekolah). Putrajaya: Bahagian Pendidikan Guru.

Malik Badri. (2000). Contemplation: an Islamic Psychospiritual study. London: Cambridge University Press.

Marin, L.M. \& Halpern, D. F. (2011). Pedagogy For Developing Critical Thinking In Adolescents: Explicit instruction produces greatest gains. Thinking Skills and Creativity, 6, 1-13

Meyers, C. (1986). Teaching Students to Think Critically: A Guide for Faculty in All Disciplines. California: Jossey-Bass Inc. Publishers.

Misnan Jemali. (2008). Amalan Pengajaran Guru dalam Pengajaran dan Pembelajaran Tilawah al-Qur'an Sekolah Menengah. Tesis Dr. Fal., Fakulti Pendidikan, Universiti Kebangsaan Malaysia.

Mohd Aderi \& Ahmad Yunus. (2012). Teaching of Islamic Doctrine And Beliefs in School Subject Content Knowledge and Pedagogical Considerations. International Journal of Humanities and Social Science, 2(11), 258-264.

Mohd Zaidi Ismail. (2013). Kerangka Aqal-Naqal dan Pelan Pembangunan Pendidikan Malaysia 2013-2025: Beberapa Catatan Pemerhatian Awal. Seminar Pemerkasaan Pengajaran Agama Islam di Malaysia: Menilai Cabaran Semasa Guru Pendidikan Islam. Anjuran IKIM dan KPM, 24-25 Sept.

Mohd Zaidi Ismail. (2014). Islam \& Higher-order Thinking: An Overview. Kuala Lumpur: Penerbit IKIM.

Muhammad Qutb. (2001). Manhaj al-Tarbiyah al-Islamiyyah. Juzu' awwal (Fi Nazdriyah). Kaherah: Darul Shorouk.

Muhammad Rashidi Wahab \& Mohd Faizul Azmi. (2013). Kedudukan Akal dalam Pendalilan Akidah. Jurnal Teknologi, 63 (1), 31-39.

Natale, S. \& Ricci, F. (2006). Critical Thinking in Organizations. Team Performance Management: An International Journal, 12 (7/8), 272 - 277.

Noor Hisham Md. Nawi. (2014). Sinergisme Pemikiran Islam Kritis Kreatif. Kelantan: Penerbit Universiti Malaysia Kelantan.

Noornajihan Jaafar. (2014). Pengaruh Efikasi Kendiri dan Faktor Persekitaran Terhadap Kualiti Guru Pendidikan Islam Sekolah Menengah Kebangsaan. Tesis Dr. Fal., Fakulti Pendidikan, Universiti Kebangsaan Malaysia.

Norris, S.P. (1985). Synthesis of Research on Critical Thinking. Educational Leadership, 40-45.

Nurul Asiah Fasehah Muhamad. (2015). Pengaruh Tahap Kepercayaan Epistemologi Islam dan Tahap Konsep Kendiri Terhadap Amalan Pengajaran Guru Pendidikan Islam. Tesis Dr. Fal., Fakulti Pendidikan, Universiti Kebangsaan Malaysia.

Parwazalam Abdul Rauf, Syed Kamaruzaman Syed Ali, Aliza Aluwi \& Nor Afizah Mohd Noor. (2014). The Effect of School Culture on The Management of Professional Development in Secondary Schools in Malaysia. The Malaysian Online Journal of Educational Science, 2(3), 41-52.

Paul, R. (1990). Critical thinking: What, Why and How? Dlm. Binker, A. J. A. Critical Thinking: What every person needs to survive in a rapidly changing world?, Hlm. 45-56. Rohnert Park: Sonoma State University.

Phillips, J.A. (1997). Pengajaran Kemahiran Berfikir: Teori dan Amalan. Kuala Lumpur: Utusan Publications and Distributors Sdn. Bhd.

Points, G.L. (2003). Critical thinking and intrinsic motivation in secondary science. Tesis Master of Education, Watson School of Education, University of Carolina, Wilmington.

Portal MyIIUM. (2015). Diakses daripada http://my.iium.edu.my/portal/page/portal/myiium_main_v3 [19 Oktober 2015].

Preus, B. (2012). Authentic Instruction For $21^{\text {st }}$ Century Learning: Higher Order Thinking In An Inclusive School. American Secondary Education, 40(3) Summer 2013, 59-79.

Rahimah Embong, Rosnani Hashim \& Yuslaini Yunus. (2013). Islamic Integrated Curriculum (IIC) for the Transformation of Islamic Education System in Malaysia Prosiding Seminar Kebangsaan Majlis Dekan Pendidikan IPTA 2013. Kuala Lumpur: Institute of Education International Islamic University Malaysia, 611-629.

Rahmat Soe'oed. (2005). Keberkesanan Aras Soalan Dalam Pengajaran Bahasa Indonesia Terhadap Kemahiran Berfikir Kritis Pelajar Sekolah Menengah Rendah di Kalimantan Timur, Indonesia. Tesis Dr. Fal., Fakulti Pendidikan Universiti Kebangsaan Malaysia.

Raths, L.E., Wassermann, S., Jonas, A. \& Rothstein, A. (1986). Teaching for Thinking: Theory, Strategies \& Activities For The Classroom. New York: Teachers College, Columbia University. 
Rosnani Hashim, Suhailah Hussien \& Juhasni Adila Juperi. (2014). The Hikmah (Wisdom) Program: A Philosophical inquiry for the teaching of Islamic education in Malaysia. Dlm. Sa'eda Buang \& Phyllis Ghim-Lian Chew. Muslim Education in the 21 ${ }^{\text {st }}$ Century. New York: Routledge: $125-141$

Rosnani Hashim. (1996). Educational Dualism in Malaysia: Implications for Theory and Practice. Kuala Lumpur: Oxford University Press.

Rosnani Hashim. (2009). Menghidupkan Semula Pedagogi Inkuiri Falsafah Di Kalangan Pendidik Dan Pelajar Islam. Jurnal Pendidikan Islam, 13 (2), 13-28.

Rosnani Hashim. (2012). Memenuhi Aspirasi Kemahiran Berfikir Dalam Pelan Pembangunan Pendidikan Malaysia 2013-2025 Menerusi Inkuiri Dan Pedagogi Filosofiyyah Dalam Kalangan Guru. Kertas kerja Persidangan Majlis Dekan Fakulti Pendidikan Universiti Teknologi Malaysia, 7-9 Oktober.

Ruggiero, V. R. (2012). Beyond Feelings: A Guide to Critical Thinking. Edisi ke-6. New York: McGraw Hills.

Sabri Mohd Salleh. (2008). Pembelajaran Pemikiran Kritis di Kalangan Pelajar Sekolah Menengah. Tesis Dr. Fal., Fakulti Pendidikan, Universiti Kebangsaan Malaysia.

Shihab, M. Quraish. (2005). Logika Agama: Kedudukan Wahyu \& Batas-batas Akal dalam Islam. Jakarta Selatan: Penerbit Lentera Hati.

Sidek Baba. (2009). Fikir dan Zikir. Kuala Lumpur: Dewan Bahasa dan Pustaka.

Siegel, H. (2010). Critical thinking. International Encyclopedia of Education, 6, 141-145.

Simon, T.C. (2010). The Relationship Between Campus Climate and the Teaching of Critical Thinking Skills In Community College Classrooms. Tesis Dr. Fal., Universiti Walden.

Suhailah Hussein. (2009). The Praxis Of Teaching Thinking: A Case Study About Student-Teachers' Experiences In The Malaysian Classrooms. The International Journal of Learning, 16(9), 117-126.

Suhailah Hussien. (2007). Critical Pedagogy, Islamisation of Knowledge and Muslim Education. Intellectual Discourse, 15(1), 85-104.

Swartz, R. J. (1991). Infusing the Teaching of Critical Thinking into Content Instruction. Dlm. Costa, A.L. Developing Minds: A Resourse Book For Teaching Thinking. Revised Edition Volume 1. USA: Association for Supervision and Curriculum Development: 177-184.

Syed Najmuddin Syed Hassan. (2009). Kajian Persepsi Pelajar Terhadap Tahap Profesionalisme Guru Pendidikan Islam MRSM. Journal of Islamic and Arabic Education, 1(2), 31-50.

Tan, C \& Ding, K. (2014). The role, developments and challenges of Islamic Education in China. Dlm. Sa'eda Buang \& Phyllis Ghim-Lian Chew. Muslim Education in the $21^{\text {st }}$ Century. New York: Routledge: 55-69.

Tang Keow Ngang \& Thanaletchumy Sulermutyrean. (2015). Kemahiran Insaniah Guru dan Penglibatan Guru dalam Membuat keputusan pengurusan sekolah. Sains Humanika, 4(1), 75-82.

Tishman, S., Jay, E., dan Perkins, D.N. (1993). Teaching for Higher Order Thinking. Theory into Practice, 32(3), 147-153.

Underbakke, M., Borg, J. M. \& Peterson, D. (1993). Researching and Developing the Knowledge Base for Teaching Higher Order Thinking. Theory into Practice, 138-146.

Wan Mohd Zahid Mohd. Noordin. (1993). Wawasan Pendidikan Agenda Pengisian. Kuala Lumpur: Nurin Enterprise.

Winn, I.J. (2004). The High Cost Of Uncritical Thinking. Phi Delta Kappan, 85(7), 496-497.

Zakaria Abdullah. (2012). Pengajaran dan Pembelajaran Berasaskan Pendekatan Berpusatkan Pelajar dalam Pendidikan Islam. Tesis Dr. Fal., Fakulti Pendidikan, Universiti Kebangsaan Malaysia.

Zakir Badwi. (1989). Pendidikan Islam Tradisional: Tujuan dan Maksudnya. Dlm. Husain, S. S \& Ashraf, S. A. (pnyt.). Krisis dalam Pendidikan Islam. Terj. Maso’od Abdul Rashid. Kuala Lumpur: Dewan Bahasa dan Pustaka \& Kementerian Pendidikan Malaysia. 